\title{
農村地域における土地利用・所有の現況との対応関係からみた 筆単位の土地利用不満意識及び利用意向に関する研究 A STUDY ON THE CONSCIOUSNESS AND THE INTENTION TO LAND USE IN RURAL SETTLEMENTS FROM THE VIEW POINT OF THE FORMATION OF DOMAINS FOR LAND USE AND LAND OWNERSHIP
}

\author{
藍 澤 宏*, 山下 仁** \\ Hiroshi AIZAWA and Masashi YAMASHITA
}

\begin{abstract}
This paper analizes the discontented consiousness and the intention to use land, the distributions of them, and the attributes of thier owners in rural settlements from the view point of the formation of domains for land use and land ownership. This study confirms the following :

1. The distributions differ in diffrent consiousness or diffrent intention to use land.

The discontented consiousness to use land is related with the zone which the change of land use or the debt and credit of farmland appeared. And there are some intentions of acquiring house lots in central and middle zone in area or maintaining land use with no discontent in outskirts of area.

2. The correspondence of the distributions which reflecting the consiousness and the intention to use land with the attributes of thier owners exists.

There are some relations between the intention of acquiring house lots in central zone of area with new moved nonfarmers which have diminutive house lots or between the intention of acquiring farmland with farmers which manage positively in outskirts of area, and others.

3. The correspondence of the distributions which reflecting the consiousness and the intention to use land with the formation of domains for land use and land ownership exists, too.

For example, farmland shifted utilization of land to house use in central zone of area, farmland for debt and credit in border of the settlement, a group of diminutive lots for house or farm, a gathering and dispersion of land ownership by farmer, and others are related with the discontented consiousness and the intention to use land.
\end{abstract}

Keywords : land use planning, rural region, consciousness, intention

1.はじめに

\section{(1) 研究の背景亡目的}

近年, 農村地域では農村の居住者の多様化に伴い, 農 用地や非農用地などの土地利用内容や，その利用に対す る不満意識・意向も様々になっている。また，離農や高 龄化による耕作放棄地の増加や無秩序な非農用地の増大 は，生活・生産の場として調和ある集落の空間構成を改 変させている。そこで, 土地所有者の土地利用不満・意 向を潜在的な土地の需要と供給として考え，長期的な土 地利用の担保条件として土地利用計画に組込むことは有 意義なことであるばかりではなく，利用不満意識と利用 意向および利用現況との関係を明らかにすることは今後 の土地利用の重要な計画要件の 1 つとなる。本研究では, 農村地域における一筆単位の土地筆の利用不満意識と利 用意向について, その内容と位置分布, 並びに土地利用・
土地所有の現況の域形成との対応関係を明らかにするこ とにより，土地利用に対する意識・意向からみた現況の 奏態と計画上の課題を求めることを目的とする。

\section{(2) 研究の方法}

研究の方法として, 研究対象地域の全土地所有者につ いて，所有筆に対する一筆ごとの利用上の不満意識と今 後の利用意向を把握する。土地所有者の個々の利用不満 意識および利用意向に関しては,所有規模等の所有者(所 有主体) の属性の相違や，居住宅地の地域の属性の違い による共通点と相違点，さらに意識・意向の表出する土 地筆の位置分布の特徵については土地利用・土地所有の 現況の域形成との対応関係から明らかにしていく。

その際，第一に，利用不満意識では，所有筆の地目を 「宅地」「農地」「その他の地目」の 3 つにまとめ,それ ぞれの利用不満の特性を考察する涪1。利用不満内容は,
* 東京工業大学 助教授. 工博

** 東京工業大学 大学院生
Associate Prof. of Tokyo Institute of Technology, Dr. Eng.

Graduate Student of Tokyo Institute of Technology 
その土地自体に対する利用不満としての素地条件（規 模・形状）に対する不満，周囲の状況との関係で生ずる 利用不満としての環境条件（接道・水はけ・日照・通 風・周囲の土地利用）に対する不満，さらに農地筆では 地力・家からの距離・利用規制，およびその他の利用不 満に分類し，筆ごとにその内容を求め，内容別の不満筆 の位置分布と不満筆を持つ所有主体の属性について考察 を行う。利用意向では, 居住宅地の拡大・縮小並びに 2 ・ 3 男用の宅地取得, 農地の拡大・縮小, 並びに商店・貸 家等の規模拡大等，所有主体単位の土地利用の意向内容 と,さらに具体的な土地に対する処分・利用転換 (転用) 意向を持つものについては実践的な処分・取得意向とし て, 所有主体の属性・利用不満内容との対応関係, 並び に意向別の所有筆の位置分布について考察を行った。

また，第二として土地利用・所有の現況の「域」形成 との対応関係については，土地台帳および転用台帳等の 台帳デー夕に基づき土地利用・土地所有の現況のそれぞ れの域形成を求め, 利用不満および利用意向の筆分布と の対応関係からこれらの要因並びに土地利用の調整の ための要件を明らかにする。そのために土地利用の現況 では, 利用域の変容として過去 15 年間の農地転用筆の 位置分布，利用の流動化を表すものとして貸借筆の位置 分布，および素地条件としての筆規模別の宅地筆・農地 筆の位置分布についてそれぞれ考察する。土地所有の現 況では，集落における属地領域内の所有筆のま之まりと 所有主体の所有規模との関係を表すものとして中心 ・中 間・周辺地区の各集落立地別の経営農地規模類型による 農地筆の位置分布を考察する。

分析の方法としては，所有主体の属性に関して「居住 位置」「所得構成」「居住歷」「宅地規模」「経営農地規模」 「集落」の 6 つ事柄について比較を行う。居住位置では 宅地が密集する地区の中心部・農用地指定区域に属する 地区周辺部，およびその中間に位置する地区中間部の 3 地域に区分する。所得構成ではアンケート調査により農 業収入之農外収入の割合によって専業農家・一兼農家・ 二兼農家・非農家とする。居住歴では同じくアンケート 調査により，この地区に住み始めた時期を明治期および それ以前・大正期および戦前・終戦後・高度経済成長 期・近年の 5 つに区分する。宅地規模之経営農地規模で は土地台帳および農家台帳により規模を集計しランクを 付ける。集落では各集落を前記した居住位置の区分に合 わせて中心・中間・周辺と位置付け，それぞれについて 考察する。

\section{(3) 調查対象地区の位置付けと調查概要}

調査対象地の選定および調査の概要については，集居 および散居集落を含み，地区内への人口流入と非農用地 化が顕在化している山形県飯豊町の町場中心である $\mathrm{T}$ 地 区を選定し，地区内における 10 集落, 約 5800 筆の土

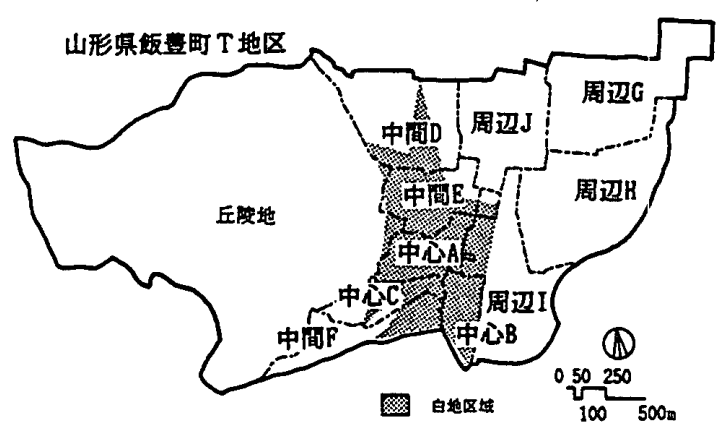

図一1調查対象地および集落の位䣯付け

表一1 アンケート調查概要と所有主体属性（户数）

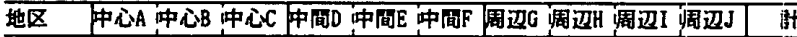

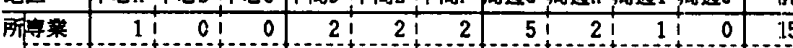

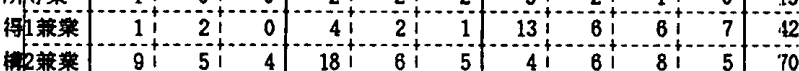

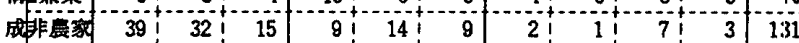

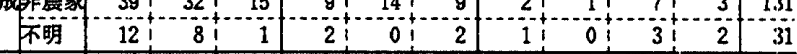
\begin{tabular}{l|lll|llllllll|l}
\hline 居明治 & $6 !$ & $1 !$ & 2 & $20 !$ & $11 !$ & 7 & $18 !$ & $13 !$ & $15 !$ & 11 & 104
\end{tabular}

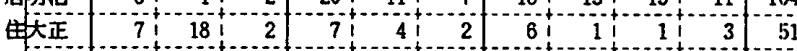

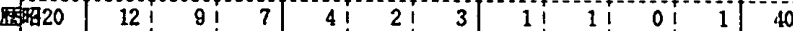

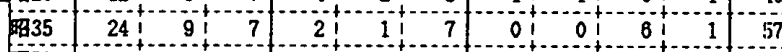

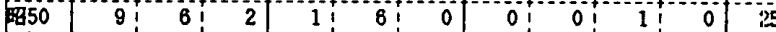

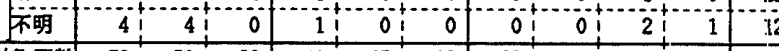

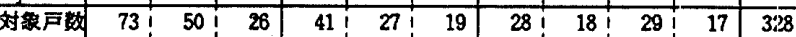

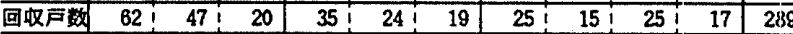

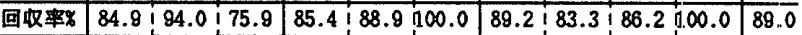

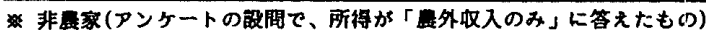

表一2 集落立地別宅地規模分布（可数）

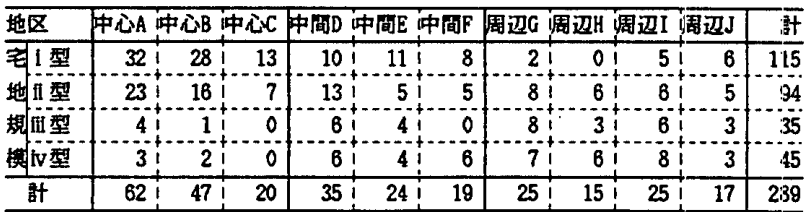

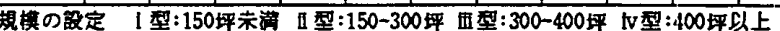

表一3 集落立地別経営農地規模分布（戸数）

\begin{tabular}{|c|c|c|c|c|}
\hline 地区 & 中心A 中心B 中心C & 中闰D 中面E 中阅F & 周䢞 周迦 周辺I 閣辺J & If \\
\hline 释I型 & $\begin{array}{llll}0 & 1 & 0\end{array}$ & 4131 & $\begin{array}{lllll}18 & 11 & 7 & 6\end{array}$ & 54 \\
\hline 学II 型 & $1 !$ & $2 !$ & $1 !$ & 12 \\
\hline 到 & 01 & $5 i$ & 51 & 20 \\
\hline 地 & 81 & 11 & 21 & 31 \\
\hline 规等 & 18 & 81 & 1 & 76 \\
\hline 楐行型 & 36 & $5 !$ & 01 & 10 \\
\hline 㪊 & $62 ! 47 !$ & $24 !$ & $15 !$ & 285 \\
\hline & $\mathrm{V}$ 列: $0.5 \mathrm{hg}$ & 11 11 & $.5 \mathrm{ha}$ & \\
\hline
\end{tabular}

地についての土地台帳・農家台帳・転用台帳の解析，お よび土地所有者に対する 1 筆ごとの利用アンケートの䦚 查分析を行った泣2!。対象地である T地区は，地区中心 部では宅地が集積する密居形態をとり，中間部では集屋 形態をとり，周辺部では围場整備の行われた水时地帯に 宅地が散在する散居形態を形成している。また，中心部 には町役場・町民センター・中高等学校等の拠点公共施 設が設置されている。

対象地の各集落の位置付けを図一1に，また，アンケー卜調査の概要之対象地における集落立地別の宅地規模分 布および経営農地規模分布を表一1 から表--3に示 す:ㅣ)。 


\section{2. 筆単位の土地利用不満意識と不満筆の分布}

（1）不満内容別にみた不満筆の位置分布

地目分類別の利用不満内容を表一 4 に，内容別の不満 筆の位置分布を図一2 および図一 3 に示す泣4!。図中の記 号は, それぞれの不満内容に当たる主体数の, 属性ごと の各項の主体総数に対する割合（\%）を表している。

所有筆に対する利用不満内容は宅地筆について全体の 約半数, 農地筆が 3 割弱, その他の地目筆が約 1 割であ り，宅地筆の利用に対する不満が高くなっている。その 内容では，宅地筆に対しては全般に規模・形状の素地条 件, 接道・水はけ等の環境条件に不満が高いが, 日照・ 周囲の土地利用等の不満はやや低くなっている。農地筆 に対しては，接道・水はけといった環境条件に関する不 満の他に，耕作距離・利用規制等の筆の所有位置に関連 する不満もみられる。その他の地目筆では，全体的に宅 地筆・農地筆に比べ不満意識は少ないが，あき地や山林 なよ゙の地目で不満があり，その内容は「規模」「家から の距離」等になっている (表一 4 )。

表一4 利用地目別の所有筆ごとの利用不満内容 (複数回答)

\begin{tabular}{|c|c|c|c|c|c|c|c|c|c|c|c|c|c|}
\hline & & & & & & & & & & & & 単他 & $(+5)$ \\
\hline 不湖内铝 & 荣地 & 案件 & & & 贊条件 & & & & 刀他の & 策件 & & 原满 & 不消 \\
\hline 利用地目 & 㚘模 & 形状 & 摇道 & 水细 & 旦照 & 通風 & 周聿 & 地力 & 品襍 & 瞡制 & 他 & おり & $12 L$ \\
\hline 宅地 & 51 & 46 & 49 & 38 & 28 & 7 & 22 & - & 1 &.- & 18 & 182 & 143 \\
\hline 田 & 11 & 21 & 16 & 13 & 6 & - & 5 & 1 & 9 & 6 & 1 & 77 & 601 \\
\hline 姆 & 2 & 2 & 6 & 4 & 8 & $=$ & $=$ & $\ddot{1}$ & 7 & $=$ & $=$ & 49 & 198 \\
\hline ハウス & $=$ & $\because$ & - & $\because$ & - & - & $=$ & $=$ & $\because$ & $=$ & $=$ & 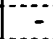 & 1 \\
\hline 休耕地 & 4 & $\overline{3}$ & $\ddot{2}$ & - & $=$ & $\because$ & $=$ & 2 & 2 & - & 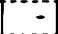 & 5 & 31 \\
\hline 巢踭固 & $\because$ & $\because$ & $\because$ & $\because$ & $\because$ & - & - & $\because$ & $=$ & - & - & $\because$ & 1 \\
\hline あき地 & 1 & 2 & - & $\therefore$ & - & - & 1 & $=$ & 4 & - & 4. & 15 & 37 \\
\hline 物场 & 2 & $\because$ & $=$ & - & $\because$ & $=$ & $\because$ & $\because$ & $\overline{1}$ & - & $\because$ & 3 & 17 \\
\hline 宣事䀦 & - & - & - & $=$ & - & - & $=$ & $=$ & $=$ & $=$ & $=$ & $\because$ & 16 \\
\hline 要物用垉 & 1 & 1 & - & 1 & - & $\because$ & - & $=$ & - & $\ddot{1}$ & $\because$ & $\ddot{2}$ & 11 \\
\hline 平的林 & $=$ & $\because$ & $=$ & $\overline{-}$ & - & $\because$ & $\because$ & $\because$ & - & $\because$ & 3 & 3 & 7 \\
\hline 山林 & 2 & - & 3 & - & $=$ & - & 2 & 2 & 1 & - & 1 & 6 & 140 \\
\hline 地 & $=$ & $=$ & $=$ & - & $\because$ & $=$ & $=$ & $=$ & 1 & - & $=$ & 3 & 68 \\
\hline その他 & 2 & 2 & 1 & $\because$ & - & - & $\because$ & $=$ & 2 & - & 1 & 8 & 85 \\
\hline 合 㩆 & 76 & 77 & 77 & 56 & 40 & 7 & 30 & $B$ & 28 & 7 & 28 & 353 & 1366 \\
\hline
\end{tabular}

不満内容とともに位置分布を見ると（図一 $2 \cdot 3)$, 宅 地筆では地区の中心および中間部で不満筆が多くなり， その内容では, 周辺部で接道条件・水はけ, 中心部で規 模・形状および周囲の環境に関する項目，中間部で全般 的な項目にそれぞれ不満があり，宅地筆が密集する地区 の中心における素地条件に対する不满と围場内に宅地筆 が点在する地区周辺部における環境条件に対する不満と いった居住位置の相違による利用不満内容の違いがある ことが示される。一方, 農地筆では戊場整備されている 地区周辺部での規模, 整備されていない中間部・中心部 での水はけ・接道条件および耕作距離と圃場整備の有無 や宅地筆之農地筆の介在状況による相違がみられる。ま た, その他の地目筆では丘陵部での家からの距離が主な

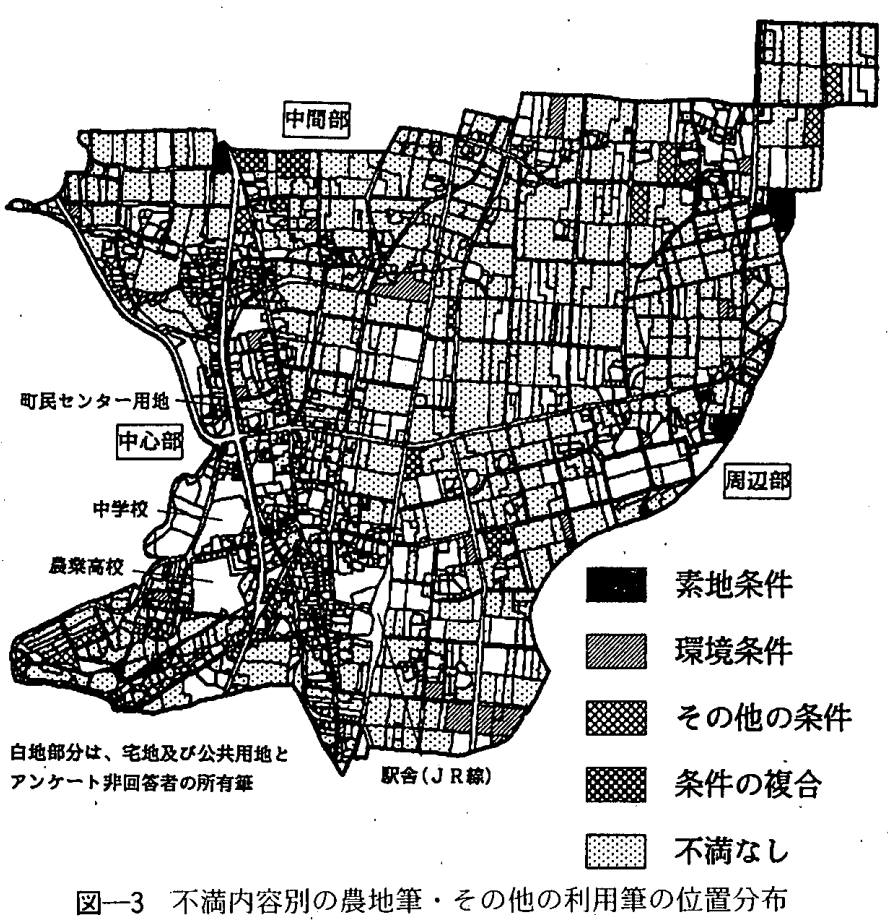

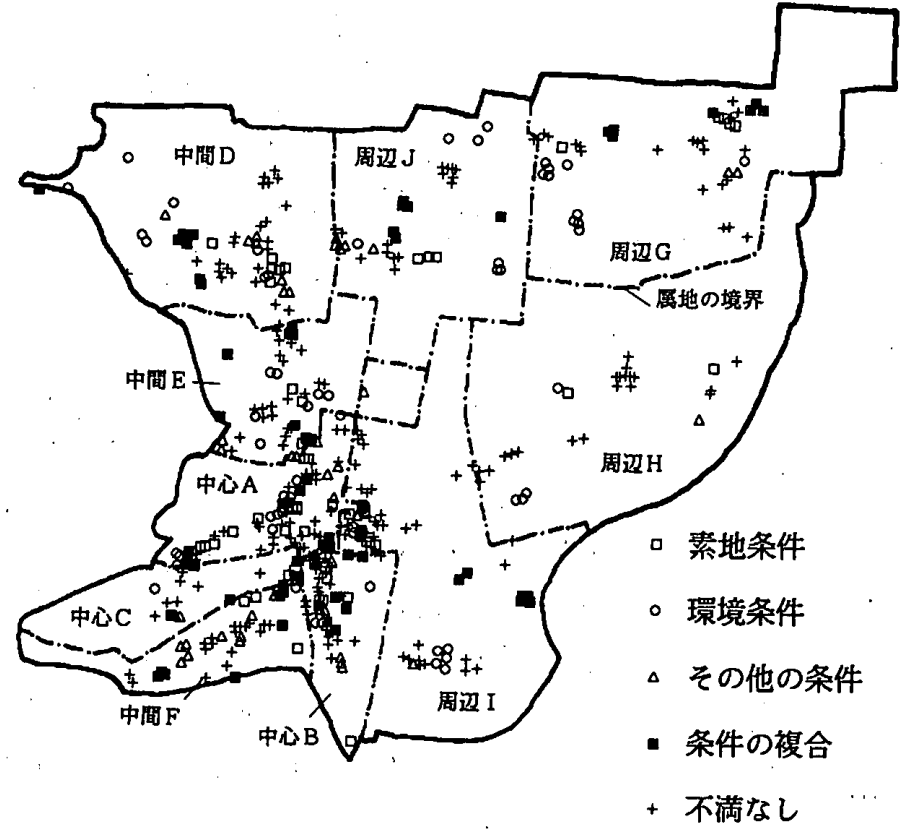

図一2 不満内容別の宅地筆の位置分布

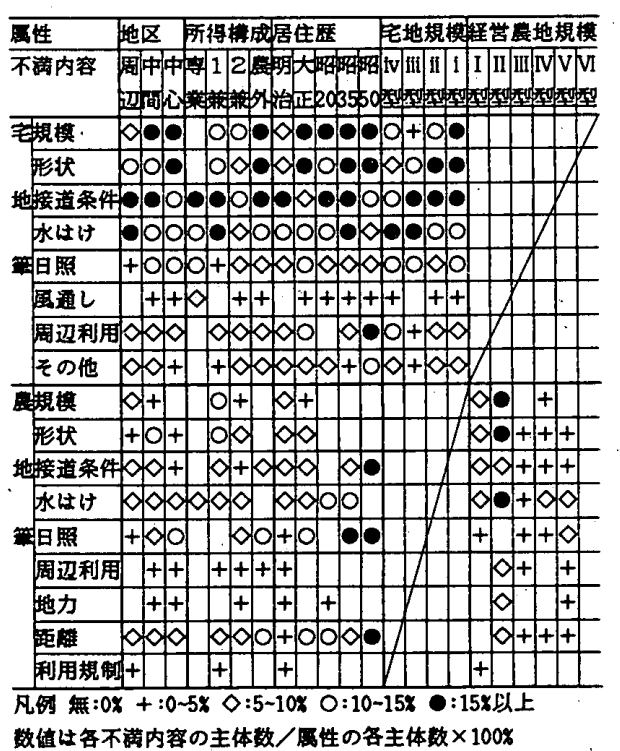

図一4 所有主体単位による所有筆の属性別の利用不満内容 
不満内容として存在する。

（2）利用不満意識と所有主体の属性

次に，所有主体単位による所有主体の属性別の利用不 満内容を図一 4 に示す泟5!。図中の数值は, 各属性ごとの 不満内容に対する割合を表している。

宅地筆についてみると, 非農家および居住歴 4 期の昭 和 35 年から 50 年の間の転入主体で特に, 規模・形状の 素地条件に対する不満が高く，また，1兼の農家では接 道・水はけ・周囲の土地利用などの環境条件に対する不 満があり，属性による不満内容の違いがみられる。この ことから, 従来から居住する農家と新たに転入してくる 非農家の宅地筆の利用意識が異なることが示される。

農地筆については，専業農家では利用に対する不満は 低いが，全般的に非農家から 1 兼農家へいくほど規模・ 形状，接道条件・水はけ等の内容で不満が高くなり，農 業への依存度が高い農家ほど，規模・形状といった農地 自体の素地条件へ不満の内容が移行する傾向を持つ。ま た, 経営規模でみると, 2 ha 以上の I 型農家と $1.5 \sim 2$ ha の II 型農家で不満の出方に差があり, 中規模農家が 大規模農家より利用の不満が高いことを表している。

その他の地目筆では，農家とのかかわりが低い非農家 で不満が生じており, 農業経営主体ではその他の地目筆 は意識上，農地筆・宅地筆に次いで副次的な所有地に なっている傾向がみられる。

以上により，筆単位の土地利用の不満意識と不満筆の 分布について，1）不満内容とその分布では，宅地が密 集する中心部での接道・水はけ等の環境条件への不満,

また，固場が末整備である中心部・中間部での農地に対 する利用の不満など，その位置における現況の土地利用 の奏態に即した不満内容が現れること，2）利用不満を 持つ所有主体の属性との対応では, 中心部での新規来住 非農家主体の宅地筆不満やその他の地目筆の不満, 並び に中間部・周辺部での一兼農家主体の農地筆の素地条件 への不満, 中心部の非農家の所有する乘離農地への環境 条件への不満等, 属性により不満内容に相違がみられる ことが明らかになった。

\section{3. 所有主体単位の土地利用意向および意向別による所 有筆分布}

\section{（1）所有主体単位による土地利用の意向内容}

土地利用に対する意向と所有主体の属性との関係，並 びに将来的な潜在的土地供給の対象地に大きくかかわり を持つと考えられる意向内容別にみた所有筆の位置分布 の実態を明らかにするために，所有主体単位の土地利用 意向について意向内容により所有主体を分類し, 意向と 不満意識との対応関係，および意向別にみた所有筆の位 置分布について考察を行った。まず, 所有主体の属性別 の利用意向の内容について図一 5 に示す。図の上段は宅

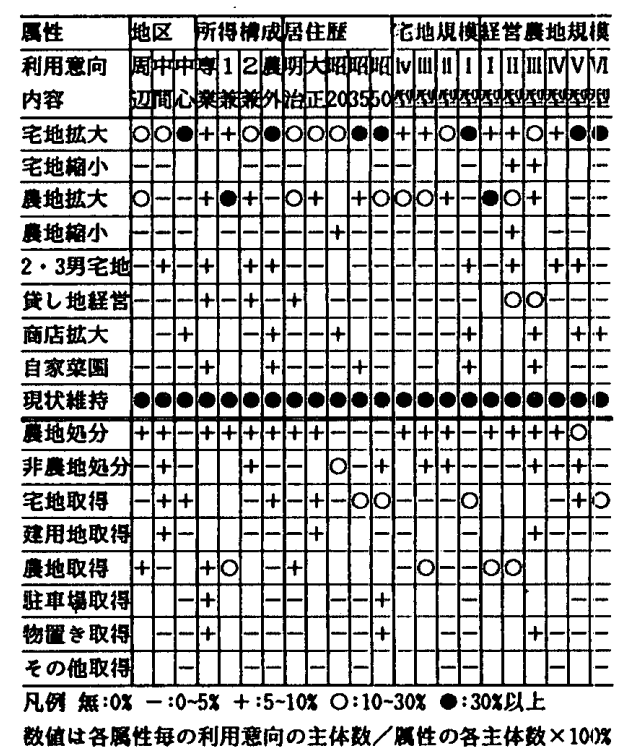

図一5 所有主体単位による所有筆の属性別の利用意向内容

地筆取得や農地筆拡大・縮小といった家としての土地利 用意向を，下段は具体的な取得や処分・転用等の夷践的 な意向 ${ }^{\ddagger 6}$ について，それぞれの属性に対する意向を持 つ主体数の割合を表している。

意向内容をみると, 現状維持意向が全体の約 6 割で疅 も多く，次いで宅地規模拡大意向が 2 割強，農地規模拡 大意向が 1 割存在し，自家菜園の取得等のその他の意何 は $5 \%$ 程度になっている。

宅地に対する利用意向では, 主に規模拡大・縮小意向, $2 \cdot 3$ 男用宅地取得意向, 現時点で実際に拡大希望地を 持っている実践的取得意向，および所有筆の地目変更に よる宅地化意向が存在する。属性での対応では地区中心 部で規模拡大・夷践的取得意向が共に多く，中間部でも 取得意向がみられる。このことは現在の宅地規模が小さ い昭和 35 年以降に転入した非農家主体の規模拡大意向 が特に強いことを示している。

また，農地に対する利用意向では，規模拡大・縮小意 向，貸し地経営意向，および実践的処分・取得意向等が ある。規模拡大意向を持つ所有主体の約 3 割では実践的 な取得意向も持っており，営農に対する積極性がみられ るとともに, 経営規模の大きな農家の農業収入における 所得増に対する強い意識が同われる。所得構成別では, 拡大・取得意向は非農家 $\rightarrow 2$ 兼農家 $\rightarrow 1$ 兼農家の順で高 く, 専業農家では低い。一方, 縮小・処分意向は全体的 に 1 割弱で,小規模経営農家が他に比べ高い傾向があり， 経営規模の相違による利用意向の違いが現れている。

その他の利用に対する利用意向では，地区中心部の居 住歴が短かく宅地規模の小さい所有主体で自家菜園や駐 車場・物置場の取得意向があり，宅地取得意向々ともに この場所における宅地規模の狭小性に対する利用意向の 特徵を示している。

さらに, 利用不満意識と利用意向との対応関係につい 


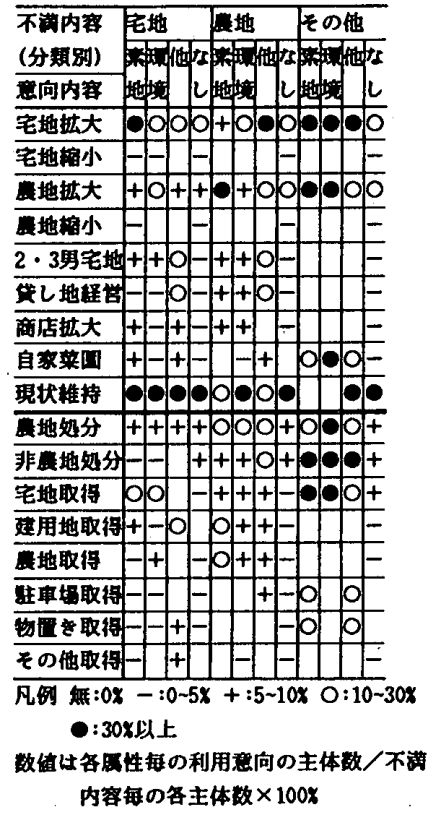

図一6 所有主体単位による利用不満意識と 利用意向との対応

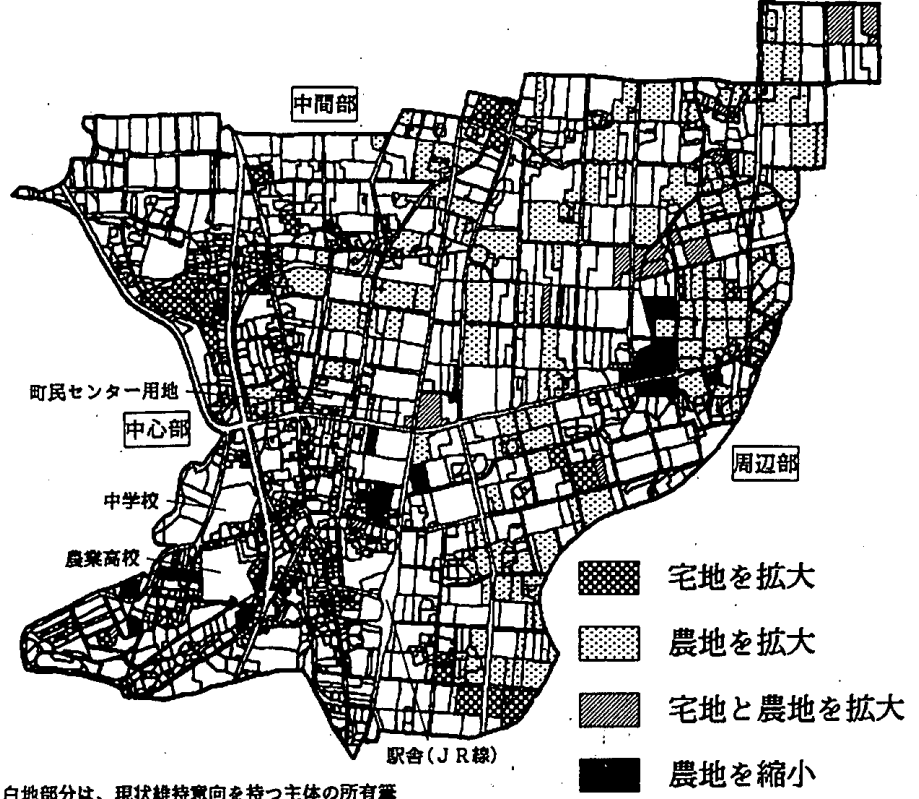
及ひ公共用地とアンケート非回答者の所有管"

図一7 規模抎大や縮小等の顕在意向を持つ所有主体の所有筆の位置分布

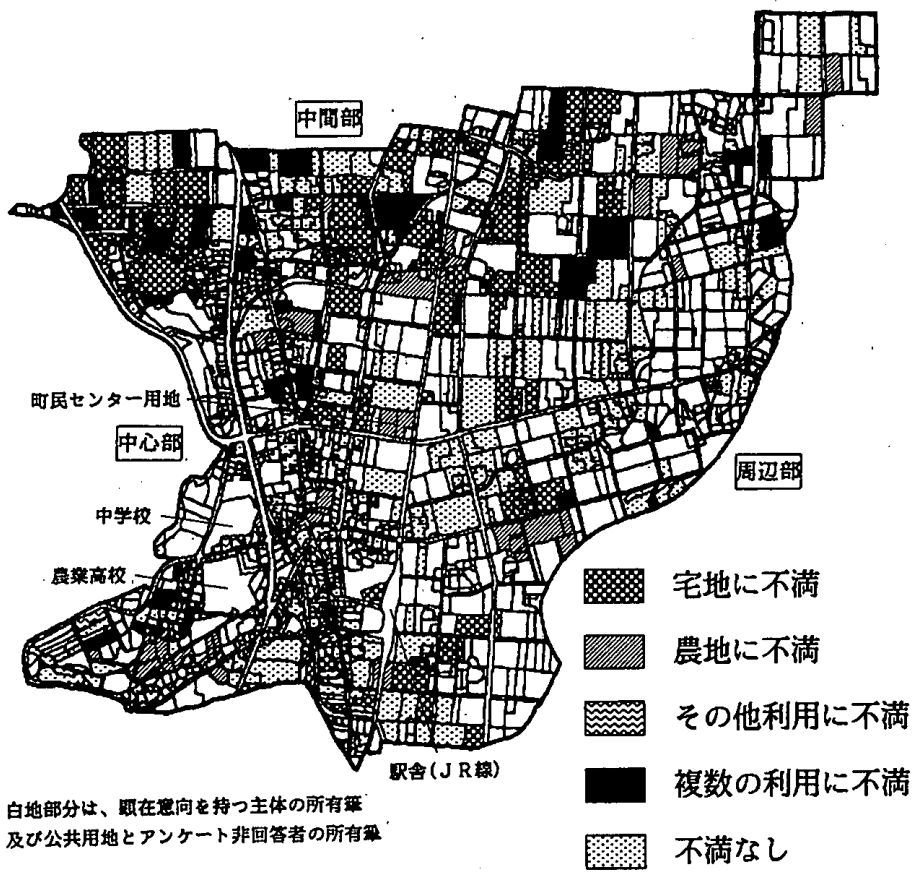

図一8 利用不満のある現状維持意向を持つ所有主体の所有筆の位置分布

一方，不満内容との対灾からみた現状維持意向を持つ 所有主体の所有筆分布をみると，現在の利用に不満が少 なく意向も現状維持である安定型意向の所有筆が周辺部 に広く分布し，宅地筆・農地筆に不満を持ちながら現状 維持意向を持つ不満意識の潜在型意向の所有筆が中心 部・周辺部にそれぞれ分布している。

すなわち, 宅地筆が密集し農地筆が介在する地区中心 部では，顕在的な規模拡大意向に対する拡大候補地がな い場合や農地利用域内に宅地筆の取得意向がある場合な ど，土地利用上の調整が必要亡される利用域となってい る(図-8)。 
以上により, 所有主体単位の土地利用意向および意向 別による所有筆分布について，1）意向内容では, 全体 的に現状維持意向が過半数を占めるが, 宅地の規模拡 大・取得意向 (2 割) や, 農地の拡大・取得および縮小・ 処分意向（1 割）等があること，2）宅地の拡大・取得 意向は地区中心部の宅地規模の小さい転入非農家主体, 農地拡大 · 取得意向は主に一兼農家主体, 農地縮小 - 処 分意向は小規模農家主体のように意向内容と所有主体属

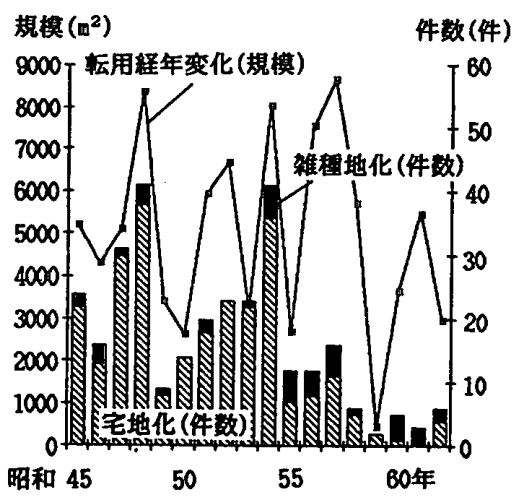

図一9 農地筆の転用件数・面積の経年変化

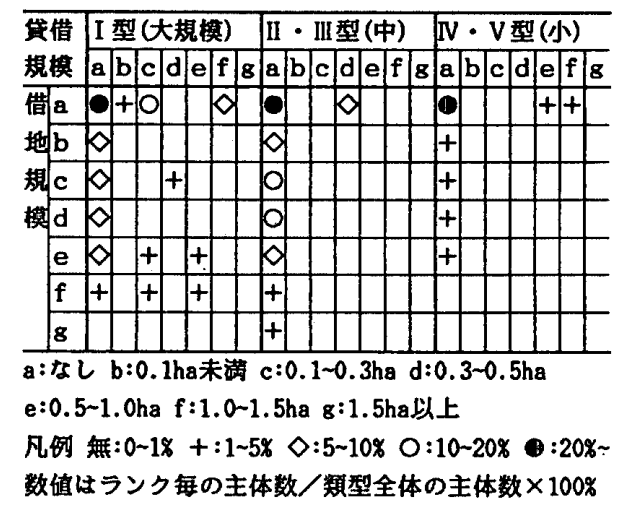

図一10 経営農地規模類型からみた農地貸借規模分布
性とが対応し，利用不満意識とも対応すること，3）利 用意向からみた所有筆分布では，意向内容によって所有 主体ごとの所有筆の分布する位置がゾーン化し，その不 満内容および意向内容がその地域における重点的な整備 課題となっていること，が明らかになった。

4. 土地利用・土地所有の現況と利用不満・意问との对 応

（1）農地転用筆・貸借筆，および筆規模の分布からみ た土地利用の現況との対応

過去 15 年間の農地筆の転用件数の経年変化と農地貸 借規模分布を図一 9 ・図一10に，さらにその転用筆およ び貸借筆の位置分布を図一11 に示す。

農地転用は小規模宅地への転用が多いが，昭和 60 年 以降では大規模な面積を必要とする駐車場や資材置場八 の転用件数が増加している。農地の貸借関係では地区内 における地主小作関係の貸借と転作を目的とする地区外 への貸借がある。これらを位置分布でみると，㷧用地区 域における白地区域に含まれる地区中心部の県道沿いに 5 条転用による非農用地化が多く，また，各集落の属地 境界部には貸借地が分布する。このことを利用不満・意 向との対応から考えると，地区中心部や集落属地境界部 における利用変容や利用の流動化が顕在化している域之 不満・意向が潜在化した域の重合する奏態が示され，利 用域の大きさおよび域の位圆に対する調整や，利用域队 の土地利用の純化および共生化に対する検討の必要性が 示される。

次に，宅地筆および農地筆の規模別の位置分布を図12 と図一13 に示す。宅地・農地共に規模が狭小な筆は 不満意識や規模拡大意向の多い地区中心部の生活道路江 いに多く分布している。このことは小規模農地の宅地笵

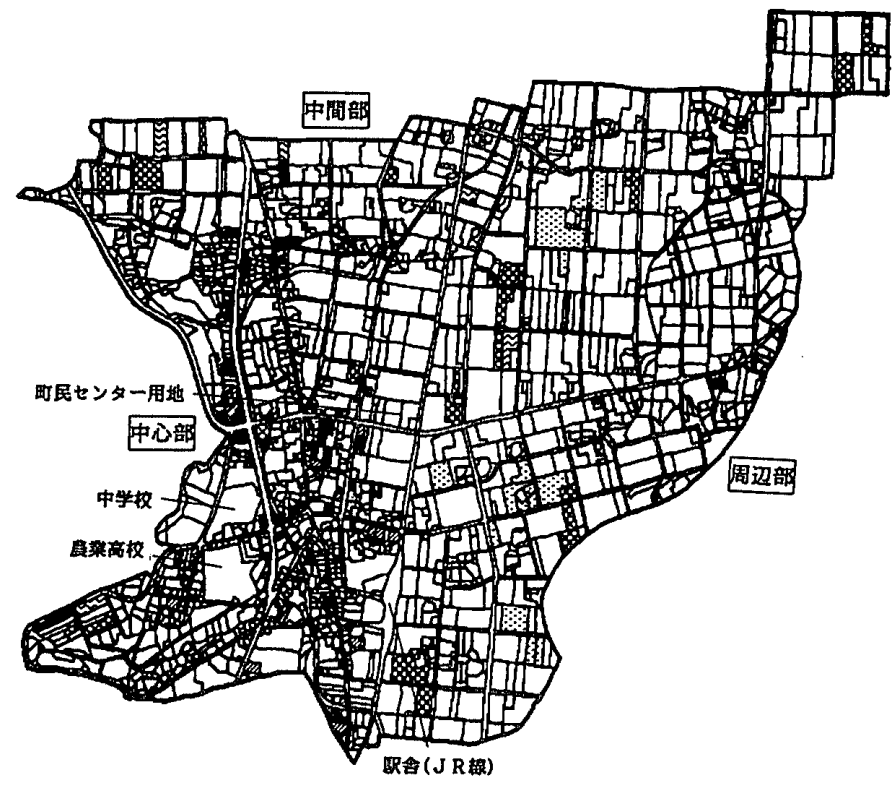

転用(昭和 45 年-51年)

4条転用 $(52$ 年- 62 年)

D条転用 $(52$ 年- 62 年)

地区内農家間の貸借

地区外農家への貸地

图一11農地転用筆および農地貸借筆の位置分布

\section{地区外農家からの借地}




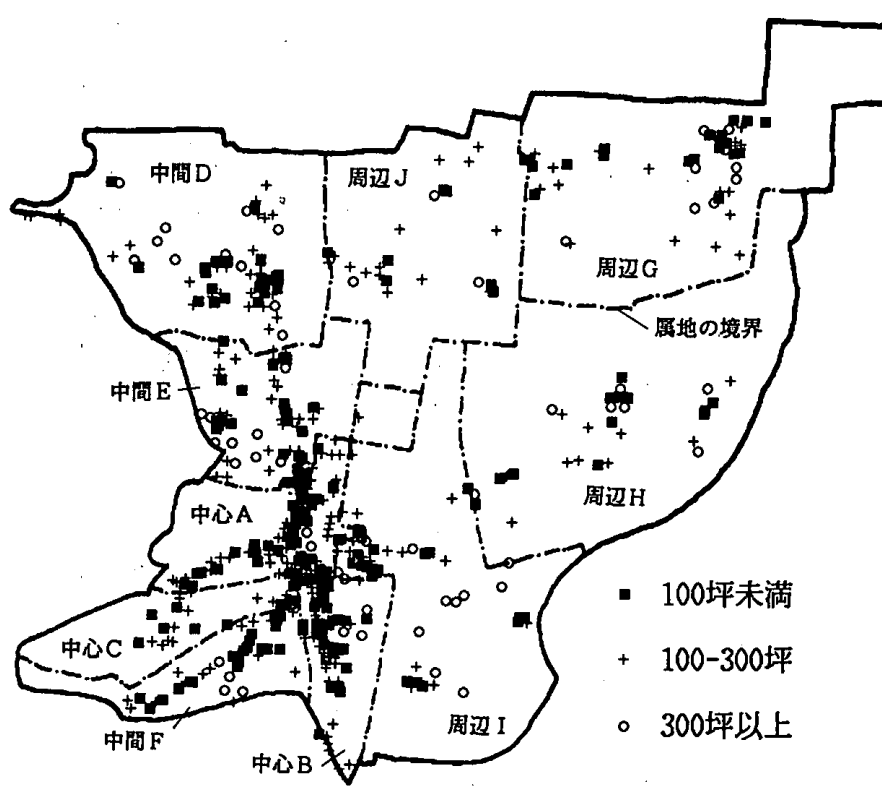

図一12 規模别の宅地筆の位置分布

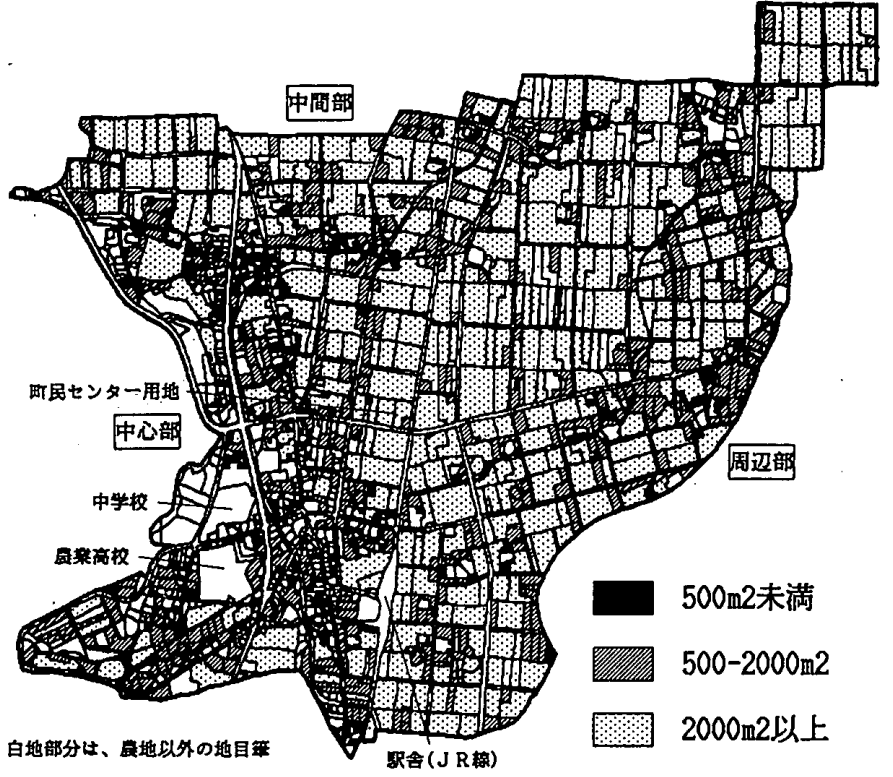

化や宅地筆の分筆等が集積しがちである地区中心部にお ける利用規制に対する課題を示すものと考えられる。

（2）集落別の経営農地規模類型による農地筆分布から みた土地所有の現況との対応

中心・中間・周辺地区の各集落立地別の経営農地規模 類型による農地筆の位置分布を図一14 に示す。

大規模農家の経営農地筆は主として地区周辺部の居住 宅地筆を中心としたその周囲に団地的に分布している が，小規模農家の農地筆は地区中心部に介在的に，丘陵 部および属地境界部には乘離的に分布している。また, 地区中間部では経営規模の異なる農家の農地筆が混在的 に分布し，これらのこしは地区周辺部において同一階層 主体による所有筆の団地的なまとまりが存在し，利用意 向に対する合意形成がされやすいのに対して，中心部お よび中間部では経営規模の異なる農家主体，あるいは農 家・非農家といった所得構成の翼なる所有主体に，より 所有が混在化するために複数属性の主体間での意向調整 が必要となることを表している。

\section{5。 まと}

米作を中心とする農村地域の町中心地区であるい形県 飯豊町 T地区 10 集落における土地所有主体による所有 筆に対する利用不満意識と利用意向，並びに台帳による 土地利用・土地所有の現況の域形成との対応関係を通じ て，以下のことが明らかになった。

（1）利用不満意識・利用意向による所有筆の「域」形 成

所有筆に対する利用不満意識・利用意向では，宅地が 密集し非農用地化が顕在化している地区中心部における 宅地筆の利用に対する規模 - 形状, 接道条件等の不満や 介在農地筆の利用に対する環境条件の不満, 複数の集落

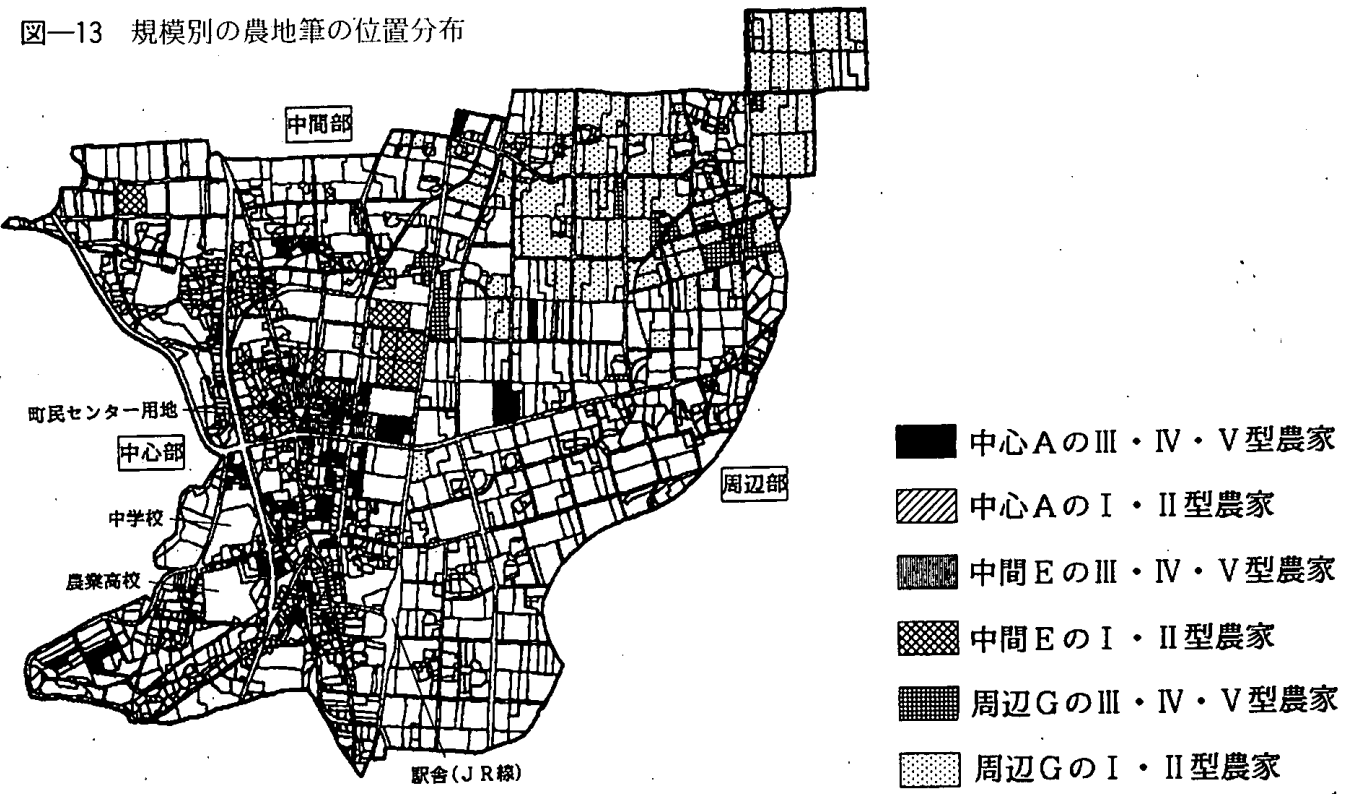

図一14 各集落立地别の経営農地規模類型からみた農地筆の位置分布 
による所有農地が混在する属地境界部における農地筆の 利用に対する接道条件・水はけ等の不満など，土地利用 に対する不満意識が地域の土地利用の変容や農地貸借, 利用の混在が生じている位置に存在する。さらに地区中 心部および中間部では不満に対応した拡大・取得意向， 周辺部では利用に不満がなく現状維持意向が存在し，そ れらの意向を持つ所有主体の所有筆の分布特性の違いが 示された。すなわち, 宅地の密集度や宅地筆と農地筆の 競合状況, 並びに圃場整備の有無など, その場所におけ る現況の土地利用の実態に即した不満意識および利用意 向があることが明らかになった。

（2）利用不満意識・利用意向の所有主体単位の属性対 応からみた主体形成

利用不満意識および利用意向の土地筆の域形成に対応 し，地区中心部の宅地筆不満および㹡大意向に対する小 規模宅地を持つ新規転入非農家主体や周辺部の農地筆拡 大意向に対する戦前からの 1 兼農家主体，および農地縮 小・処分意向に対する小規模経営農家主体等，利用意 識・利用意向と所有主体の属性との対応関係が明らかに なった。

（3）土地利用・土地所有の現況との対応関係からみた 利用不満意識・利用意向の形成要因と調整課題

地区中心部および中間部の農用地白地区域内における 4 条・5 条の農地転用筆や集落属地境界部の農地貸借筆 の位置，宅地筆および農地筆の規模分布での狭小な筆の 団地化, 並びに経営農地規模階層による所有筆の団地化 と分散化といった，それぞれの利用不満意識・利用意向 との対応関係が示され，このことから利用不満意識・利 用意向を実際の計画に移行していく過程において，今後 の利用域の大きさや位置・利用規制・意向調整等の計画 的な調整課題に対し現況の土地利用・土地所有の域形成 を把握することの有效性を明らかにした。

今後の研究の課題としては, 今回の研究により明らか にされた利用意識・利用意向による所有筆の域形成に対 して土地利用条件が異なる地域での結論の確認と, 問題 点として示した意向を持つ所有主体と持たない所有主体 の双方を含む主体間の土地利用「域」の調整方法の検討 が必要であると考える。
注

1)利用地目は,アンケート調查により所有地について 1 筆 ごとに現在の利用状況を尋ねている。

2）この調查は, 昭和 63 年 7 月に行った山形県飯豊町 T地区 土地利用計画基礎調查における地区内 1 筆地土地利用調 查を基にしている。

3）表一 1 の非農家計 131 戸と表一 3 の「農家以外」 96 戸の 35 戸の差は，農家台帳に存在する経営規模が小さい農家 の中でアンケートの所得構成の設問に「農外収入のみ」 と答えた家により生じている。

4）表一4において，アンケートに回答のあった筆数の合計 と土地台帳による地区全体の 5813 筆との差は, アンケー卜対象外である道路・水路・公共用地など 2600 篚 (47.7\%) $67 \mathrm{ha}(10.0 \%)$ ，奏際の回答が少な放った丘 陵部の山林筆 $533(9.2 \%) 329 \mathrm{ha}(48.8 \%)$ ，および回答 されなかった所有筆により生じている（今回の調查では 公共主体は聞取調查のみであり，アンケートの対象外之: なっている)。

5）図一4において, 昭和 50 年以降の居住者が農地を所有す ることについては，以前から地区内に農地を所有してい た人が，その期間に地区内に転入してきた場合に該当す る。

6）具体的な取得・処分等の意向とは，アンケート調查票で 現時点において「可能ならば取得，あるいは処分・転用 したい土地があるか」燖ね，さらに，その位置について 聞いたものをさしている。

\section{参考文献}

1）監澤 宏，山下 仁：土地の需要・供給関係からみた地 目変换筆・所有権移転筆の分布変容と土地所有主体形成 一農村地域における土地の利用域形成からみた土地利用 計画に関する基礎的研究 その 1 一, 日本建築学会計画 系論文報告集，No.408，pp.81９2，1990

2）藍澤 宏ほか 2 名：農村地域における土地利用の奏態掞 よび不渵意識・利用意向からみた土地利用形成要件に関 する研究「その1」から「その 3$\rfloor$, 日本建築学会大会学 術講演梗概集 E, pp. 933 938，1989

3）農村生活総合研究七ンター：農村地域における中心（扸 点）集落の空間構成と整備課題に関する研究，1987

4）和田照男編：地域農業振興と農地利用計画一計画実践歌 例之計画手法一, 地球社, 1986

5）冨田正彦：現代農村計画諭，東京大学出版会，1984

6) 木内信蔵：地域概諭一その理論と忍用一, 東京大学出版 会, 1968

(1990 年 6 月 10 日原稿受理, 1990 年 12 月 5 日採用決定) 